\title{
Intra-urban patterns of creative industries in polycentric city
}

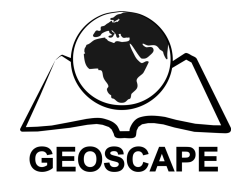

\author{
Ondřej Slach ${ }^{1 *}$ - Igor Ivan ${ }^{2}$ - Jan Ženka ${ }^{1}$ \\ - Andrej Sopkuliak ${ }^{1}$ \\ ${ }^{1}$ Department of Human Geography and Regional Development, \\ Faculty of Science, University of Ostrava, Chittussiho 10, 710 \\ oo Ostrava - Slezská Ostrava, Czech Republic \\ *ondřej.slach@osu.cz \\ ${ }^{2}$ Institute of Geoinformatics, Faculty of Mining and Geology, \\ VŠB - TU Ostrava, 17. listopadu 15, Ostrava - Poruba, 708 33, \\ Czech Republic
}

\begin{abstract}
The principal objective of this paper is to evaluate the spatial patterns of creative industries in a micro-geographic perspective. As the creative industries represent a highly heterogeneous complex, only selected creative industries were studied (culture, marketing and advertising, printing, publishing, architecture). The polycentric industrial city of Ostrava was chosen as the surveyed area. Various spatial statistical methods (e.g. nearest neighbour analysis, kernel density estimation) were applied for the needs of assessment. The results show that spatial patterns of creative industries at intra-urban level do not vary significantly from their counterparts in Western Europe. Despite the fact that Ostrava is highly industrialized polycentric city with relatively weak position of the city centre, creative industries are highly concentrated into the historical city centre and the inner city.
\end{abstract}

Key words: Creative industries; Intra-urban; Spatial patterns; Polycentric city; Ostrava

Highlights for public administration, management and planning:

- high spatial concentration of creative industries in central parts of the city indicates their potential for urban regeneration

- there is relatively low potential for the development of creative industries outside the city centre and inner city

- necessity to develop own place-based specific strategies for the development of creative industries is highlighted

Received: 26 May 2015 - Received in revised form: 17 Jun 2015 - Accepted: 19 Jun 2015

\section{Introduction}

The issue of creative industries has established itself as a topic of discussions among geographers in the recent years. According to Pratt (2013, p. 319) the geographers "played a leading role in the examination of the localisation of the cultural and creative industries, notably with respect to the clustering and urbanisation of these activities". Large part of geographical papers focus on national or inter-urban level (e.g. De
Propris et al. 2009). Studies at intra-urban level are presented less frequently (e.g. Hutton 2006; Currid, Williams 2010). Similar situation is also in Czechia, where studies of creative industries at national or regional level were executed (e.g. Bednáŕ, Grebeníček 2012), but the intra-urban level was studied only partially. The presented paper aims to (a) contribute to a better understanding of (micro) spatial organization of creative industries at intra-urban level in Central 
European post-socialist cities and also (b) contribute to the set of empirical evidence of the often neglected agglomeration studies of "more mundane, not so spectacular firms, industries, and regions" (Malmberg, Maskell 2002, p. 435). The authors draw on the case study of Ostrava, which allows for studying the spatial patterns of creative industries at intra-urban level in atypical conditions. Ostrava is highly industrialized polycentric city with relatively weak metropolitan functions (Hampl 2005), underdeveloped sector of creative industries (Slach et al. 2013), weak position of the city centre and also fragmented functional, physical and social structures. As such, it is possible to expect rather dispersed spatial pattern of creative industries in polycentric cities of this kind. Their urban centres are not likely to create significant urbanization economies that would support spatial clustering of firms in creative industries.

In the introductory part we discuss the factors influencing the spatial patterns of creative industries at intra-urban level. As the creative industries present not only conceptually (Pratt 2005; Boggs 2009), but also spatially highly heterogeneous complex of different industries (Boix 2013; Cruz, Teixeira 2015), the selected industries will be briefly introduced with emphasis on their spatial nature. A brief characteristic of the surveyed area will also be presented with respect to the fact that the analysis focuses on the intra-urban level. Further are presented data, methods, and subsequently the results. In the concluding part we discuss the achieved results and also outline the further research possibilities.

\subsection{Creative industries in intra-urban perspective}

The most frequently applied approach for defining the creative industries is the sectoral approach, which defines the creative industries as "activities which have their origin in individual creativity, skill and talent, and which have the potential for wealth and job creation through the generation and exploitation of intellectual property. The key representatives are advertising, architecture, the art and antiques market, crafts, design, designer fashion, film, interactive leisure software, music, the performing arts, publishing, software and television and radio" (DCMS 1998, p. 10). The creative industries have an "urban nature" (Lazzaretti et al. 2008) and also a high tendency to concentrate into specialized clusters within cities (Scott 2000). Besides this, the share of creative industries in urban economies stems from their position in urban hierarchy with the leading role of capital cities (Power 2003). The tendency of creative industries to spatial colocalization into clusters with dominance of central parts of the cities (mainly inner cities) stems from a large number of factors which can be the following: Firstly, markets for creative industries are characteristic with an immense degree of instability and uncertainty ("nobody knows" - Caves 2000). The uncertainty of the demand influences the character of the supply dominated by the ad hoc cooperation in the framework of the "project ecology" (Grabher 2004) with a high share of the symbolic knowledge base (Asheim et al. 2007). All these factors increase the significance of the spatial proximity (urban density), which "facilitates [...] effortless transmissions of ideas and values depend on sight or hearing. Even if the affected person has not seen or heard the influential person himself, it is often true that he knows someone who has had this personal contact. Obviously, the "ability to see or hear depreciates sharply with space" (Glaeser et al. 2000, p. 103). An important role in acquiring (informal) contacts and exchanging information is also played by cafés, clubs, or public grounds (the so-called "third places", Oldenburg 1999). Secondly, a significant factor for spatial concentration is also the market proximity, because "cultural industries tend to locate in places where cultural performance infrastructures are also present, the latter again being located in neighbourhoods where demand for their goods and services is high" (Currid, Williams 2010, p. 327). Thirdly, the workforce for creative industries (particularly artists) has also the tendency to concentrate in inner cities (Markusen 2006), which allows the companies to use the advantages of a specialized labour market (labour matching). Fourthly, the creative industries concentrate in the historic parts of cities (inner cities) with high aesthetic and symbolic value also due to the reason that the urban structure (architectural design of the 
built-up area) can stimulate invention and creativity (Drake 2003; Hutton 2004), and vice versa - the locality's image can become a component of the service or product (Molotch 2002). Besides this, such spaces are relatively well accessible, as well as providing for lower rents (minimally in comparison to city cores), which makes the creative industries (services) a significant transformation/regeneration factor for the central parts of cities (Hutton 2004).

The above mentioned factors have influence on spatial concentration of creative industries. However, simultaneously with the concentration process the factors leading towards the spatial de-concentration of creative industries also operate. Among the typical de-concentration factors we can mention the increasing role of diseconomies of agglomeration in the form of higher rents, worse accessibility (traffic congestions), or high wages (Turok 2004). Keeble and Nachum (2002) showed that the birthplace of the company founder, environmental quality, or quality of life as a whole has a high importance for localization of companies' activities outside of London (deconcentration).

Five branches of creative industries were selected for a more detailed spatial analysis: culture, printing, publishing, advertising (marketing and advertising) and architecture. The principal arguments for selection of these branches are twofold: From the perspective of number of companies, software would also rank among the largest branches; however its classification among the creative industries is highly questionable (e.g. Campbell 2014), and that is the reason for not including it. Further, we argue that the selected branches vary from the perspective of e.g. share and importance of knowledge base (for more see Asheim et al. 2007; Slach et al. 2013), spatial organization, significance of urbanization economies, etc., which will enable testing the similarities/differences in their localization/co-localization. The characteristics of the selected branches are the following:

- Culture (art) represents the core of the creative industries concept, as it is the key source of creativity (Throsby 2008). The symbolic knowledge base is dominant (Asheim et al. 2007). Operations of cultural activities are often dependent on public subsidies (Stam et al. 2008). Therefore, the public-funded cultural activities are localized not in order to maximize the profit, but to maximize the societal benefit. The cultural activities thus generally have the highest tendency to concentrate in the city centres, or eventually in inner cities (Mommaas 2004; Musterd, Deurloo 2006). Especially with the audience-oriented artistic activities, an important role is played by the centrality, or respectively their good accessibility (Ebert, Kunzmann 2007). The art also represents a strong localization factor for other (market) oriented creative industries (Currid, Williams 2010). The urbanization economies of the central parts of cities, or eventually inner cities, are then perceived as the key localization factors. Nevertheless, even in culture can be observed the de-concentration tendencies outwards the city centres, where the culture is used as a tool for regeneration of brownfields outside of city centres (see Hitters, Richards 2002).

- Publishing and printing are classified by Throsby (2008) among the so-called wider cultural industries. However, these are two quite different branches, although they may seem from the production chain perspective as closely interconnected. Publishing focuses on content origination (Pratt 2004), and as stated by HjorthAndersen (2003, p. 384) "basic functions of publishing company (is) in selecting and editing manuscripts". As an intermediary actor, a publisher mediates the content between the author and the market. On the supply side, this is a segment with high risk, as the success or failure of the work cannot be estimated in advance (see Caves 2003). A key role for localization is played by the urbanization economies, like e.g. workforce availability, or eventually the dense built environment, and in particular the existence and accessibility of "meeting places" for informal interaction, and image (reputation) of the locality (Heebels 2013). On the contrary, the printing "focuses on the transference of contents to a certain medium such as paper, metal, plastic" (Boix 2013, p. 66). This branch focuses not on the creation of the content, but on its pure reproduction, which distinguishes it significantly from publishing. Primary localization factors for printing are mainly scale economies, and for large 
companies also internal scale economies. Therefore, it can be presumed that publishing will be concentrated in the city centres/inner city, while printing will have more dispersed spatial patterns (Boix 2013).

- Advertising and architecture can be classified among the related creative industries, (Throsby 2008), or similarly as advertising into creative business services which are the source of innovation for non-creative industries (Stam et al. 2008). Advertising is perceived as a branch which significantly demonstrates the convergence of culture and economy, as it functionally integrates the culture as well as the economy (Thiel 2007). Functioning of advertising activities is based on the symbolic knowledge base (Asheim et al. 2007) with corresponding key importance of urbanization economies in the framework of central parts of cities, particularly in the form of information and project ecology ("noise" Grabher 2002), and labour pooling (Keeble, Nachum 2003). On the other hand, the larger and more successful companies tend to concentrate outside of the city centres (Kloosterman 2004). For advertising can be thus expected a high spatial concentration and a high rate of colocalization with other branches. Architecture is a part of the most of the creative industries' definitions, because "the essence of their main product - architectural design - lies in its symbolic and aesthetical content" (Kloosterman 2010, p. 861). Unlike the advertising, architecture can be classified as a traditional cultural industry (Lazzeretti et al. 2008). Apart from the symbolic knowledge base, the architecture also utilizes the technically oriented synthetic knowledge base (Strambach 2008), from which can be expected that its tendency towards spatial concentration will be lower than with the branches based purely on the synthetic knowledge base. Simultaneously, the innovative, more idea- and less technically-oriented architectonic companies tend to spatial concentration in inner cities or city centres (see Kloosterman, Stegmeijer 2004; Kloosterman 2008) and vice versa. Empirical studies of creative industries in post-socialistic countries put emphasis on their relatively similar spatial patterns, some contextual particularities however exist. The transformation process was marked by the strong economic growth of capital cities (David et al. 2013), which is reflected also by their super-dominance in representation of creative industries (Slach et al. 2013; Rehák et al. 2013). Rozentale and Lavanga (2014) also point out that creative industries at this territory differ with their lower level of internationalization, lower demand uncertainty, and in general by the lower value-added production. It is thus necessary to bear this in mind when dealing with the assessment and interpretation of the creative industries in the given context.

\section{Methods}

\subsection{Study area}

Old industrial regions can be seen as an antipole to capital cities and their metropolitan hinterland from the perspective of adaptation to postsocialistic transformation. Ostrava is an economic centre of one of such regions. Industrial history and high degree of specialization on heavy industries until now results in a relatively weak representation of creative industries in comparison to the national level (Slach et al. 2013). As the text deals mainly with the intraurban level, we will shortly outline the evolution of the main features of the city's urban (physical) structures. The physical structure can be characterized as highly heterogeneous and particularly polycentric (Bednár 2008). The first part of Ostrava (old Ostrava - eastern part of Ostrava) was formed via intensive industrialization, or respectively a spontaneous urbanization, which resulted in a spatial overlapping of factories, mines, slag heaps, residential housing, and social infrastructure (Havrlant 1980). Only in the first decades of the 20th century was partially completed the construction of administrative and societal features which gave the Ostrava's city centre the architectural and urbanistic character corresponding to its size (Vybíral 2003). After 1948 , the polycentric character of Ostrava was multiplied by the construction of new residential areas (sub-centres) in the west (Poruba) and south (Ostrava-Jih), which resulted in emergence of a city comprising three spatially divided areas arranged in the shape of an equilateral triangle 
(Kuta et al. 2005). During this period, the majority of the city centre (except for the historic core), or respectively the whole "old Ostrava", went through a controlled decline. Despite the radical socio-economic changes after 1989, the polycentric character of the city remained preserved. Simultaneously, these changes resulted in the polarization/fragmentation of the city (functional, physical, social) structures, and at the same time was triggered the spontaneous (purely market-driven) de-concentration at the level of the metropolitan region (Rumpel, Slach 2012). In this paper, we are working with a rough classification of morphogenetic zones as in Kunc et al. (2014, p. 117), where five zones are classified: historic centre, inner city, wider inner city, housing developments and villa districts, suburban zone. The first three named zones are a part of the "old Ostrava", and the others are typical for Poruba and Ostrava-Jih ("new Ostrava").

\subsection{Data and methods}

For the needs of spatial distribution analysis the data from the Registry of Economic Subjects (RES) of the Czech Statistical Office for year 2013 were used. Advantages of the RES lie in the possibility of an exact localization of a company by its address, higher detail of sectoral classification according to NACE (fifth digit; Table 3), and data up-to-dateness. On the other hand, it should be noted, that utilization of SIC/NACE has a number of weaknesses like e.g. missing exact data concerning the number of employees - only size groups of employees' number are available, and also its incompleteness (large part of subjects do not provide complete data) (more on this issue in e.g. Power 2003). Major problem of this data source is fact, that this database contains only addresses of company domicile and particular eventual addresses of branch offices are not recorded. This is not a problem of small companies. An issue related to small companies is connected to variety of branches that are declared by a company. It cannot be often clearly defined what is the dominant area defined by NACE code because orientation on particular branches are on a similar level and changing during a time. Through the geocoding, the RES data were joined with addresses on the city's territory. Thanks to this approach, it was possible to apply selected methods of point pattern analysis (Moah, Kanaroglou 2007; Rehák, Chovanec 2012). Subsequently the following methods were used: The nearest neighbour analysis works only with the distance from one point (a company) to the nearest point (another company) and compares average of these distances with expected distance between nearest points in a random pattern. The average distance between points and their nearest neighbours Ro is compared to the expected distance between points and their nearest neighbours $\mathrm{Re}$ when points are distributed randomly. This expected distance corresponds to:

$$
R_{e}=\frac{1}{2 \sqrt{\lambda}}=\frac{1}{2 \sqrt{\frac{n}{A}}}
$$

where $\lambda$ is the density of points (companies), $n$ is their number, and $A$ is the area of the studied territory (Rogerson 2010).

The share of the observed and expected average shortest distance defines nearest neighbour index (NNI). If the $\mathrm{NNI}$ equals to 0 , all points are at one spot and it is thus a perfect cluster. A maximum is then a theoretical value of 2.14 when all points are absolutely evenly distributed, or respectively the data are perfectly dispersed. If $\mathrm{NNI}$ equals to 1 , it is a random spatial pattern.

$$
\mathrm{NNI}=\frac{R_{0}}{R_{\theta}}
$$

For the analysis of spatial distribution of companies in creative industries, density methods which relate the number of individual subjects to the area are often utilized as well. Frequently, these are administrative territorial units. Nevertheless, more often are applied methods which at least partially eliminate the 
modifiable areal unit problem (MAUP) (Wong 2009) and do not work with artificially defined administrative units. A representative of such methods is also the kernel density estimation method (O'Sullivan, Unwin 2010). The kernel density estimation assigns to each point in the area an estimation of density based on the distance to other points.

The spatial aggregation is applied with respect to the infinite number of such points where the analysed territory is covered by a square grid and densities are calculated for centroids of individual cells. In general the distance between the centre of the cell and each company is calculated, and a weight which is acquired by the cell's centre for all events is determined. These weights are then summed up. It is thus an interpolation method, because it is possible to determine from the result the density of companies on the whole territory.

$$
\tilde{f}_{h}(x)=\frac{1}{n} \sum_{i=1}^{n} K_{h}\left(x-x_{i}\right)=\frac{1}{n h} \sum_{i=1}^{n} K\left(\frac{x-x_{i}}{h}\right)
$$

where $\mathrm{K}$ is a kernel non-negative function (of different shapes), $h$ defines a distance of influence (bandwidth) and $\mathrm{xi}$ are independent and identically distributed observations (companies) (Levine 2007).

The essential question when using the kernel density estimation is the setting of parameters, among which are the size of the grid cell, bandwidth, and the shape of smoothing function. The setting is dependent more on the experience of the analyst and his/her judgment. For the below shown results, the value of 150 meters for bandwidth, and pixel size of 10 meters was used after testing, together with quartic kernel function (Inspektor et al. 2014).

The co-localization of individual creative industries was assessed also at the level of basic settlement units. Instead of the original values of densities, standardized values using the z-scores were used.

$$
z=\frac{x_{i}-\bar{x}}{s}
$$

Pair correlations were calculated between the individual $z$-scores with the utilization of the Pearson correlation coefficient. The results are shown in the Table 1 and all coefficients are higher than 0.3 , and the statistical significance was proved ( $p$-value $=0.01)$.

Table 1 - Pearson correlation by selected creative industries. Source: Registry of Economic Subjects (RES) of the

\begin{tabular}{|c|c|c|c|c|c|}
\hline & Culture & $\begin{array}{l}\text { Marketing } \\
\text { and advertising }\end{array}$ & Printing & Publishing & Architecture \\
\hline Culture & 1 & $0.688^{* *}$ & $0.392^{* *}$ & $0.544^{* *}$ & $0.583^{* *}$ \\
\hline Marketing and advertising & $0.688^{* *}$ & 1 & $0.419^{* *}$ & $0.616^{* *}$ & $0.724^{* *}$ \\
\hline Printing & $0.392^{* *}$ & $0.419^{* *}$ & 1 & $0.344^{* *}$ & $0.406^{* *}$ \\
\hline Publishing & $0.544^{* *}$ & $0.616^{* *}$ & $0.344^{* *}$ & 1 & $0.536^{* *}$ \\
\hline Architecture & $0.583^{* *}$ & $0.724^{* *}$ & $0.406^{* *}$ & $0.536^{* *}$ & 1 \\
\hline
\end{tabular}
Czech Statistical Office (2013) Note: ${ }^{* *}$ Correlation is significant at the 0.01 level (2-tailed).

The assessment of spatial distribution without relation to the administrative division was applied also in the case of co-localizations, similarly as in the case of densities. As it can be seen in the maps, the individual groups of branches concentrate into similar basic settlement units. But the aim was to localize specific localities within such units and locate 
hubs. The kernel density estimation method was used again, including its settings. Only values of densities representing cells with $10 \%$ of the highest non-zero densities were selected from the resulting values. From these only those areas that had an area larger than 0.5 square kilometres were selected. An absolute intersection of the resulting areas identifies only a single area in the city centre. Nevertheless, the existence of a hub is not unambiguously conditioned by the presence of subjects in one locality, but in a sufficient proximity. Due to this reason these areas were enlarged by 250 meters, and their intersections identified three localities one large area in the city centre, and two smaller areas - one again in the city centre and second in the Ostrava-Jih district. No other hub was identified by the overlay due to absence of subjects dealing with publishing. If this branch was excluded, then the partial hubs would be localized also in Poruba, and at the border between the central district and district of Mariánské Hory and Hulváky. The previously mentioned hubs would then get even larger.

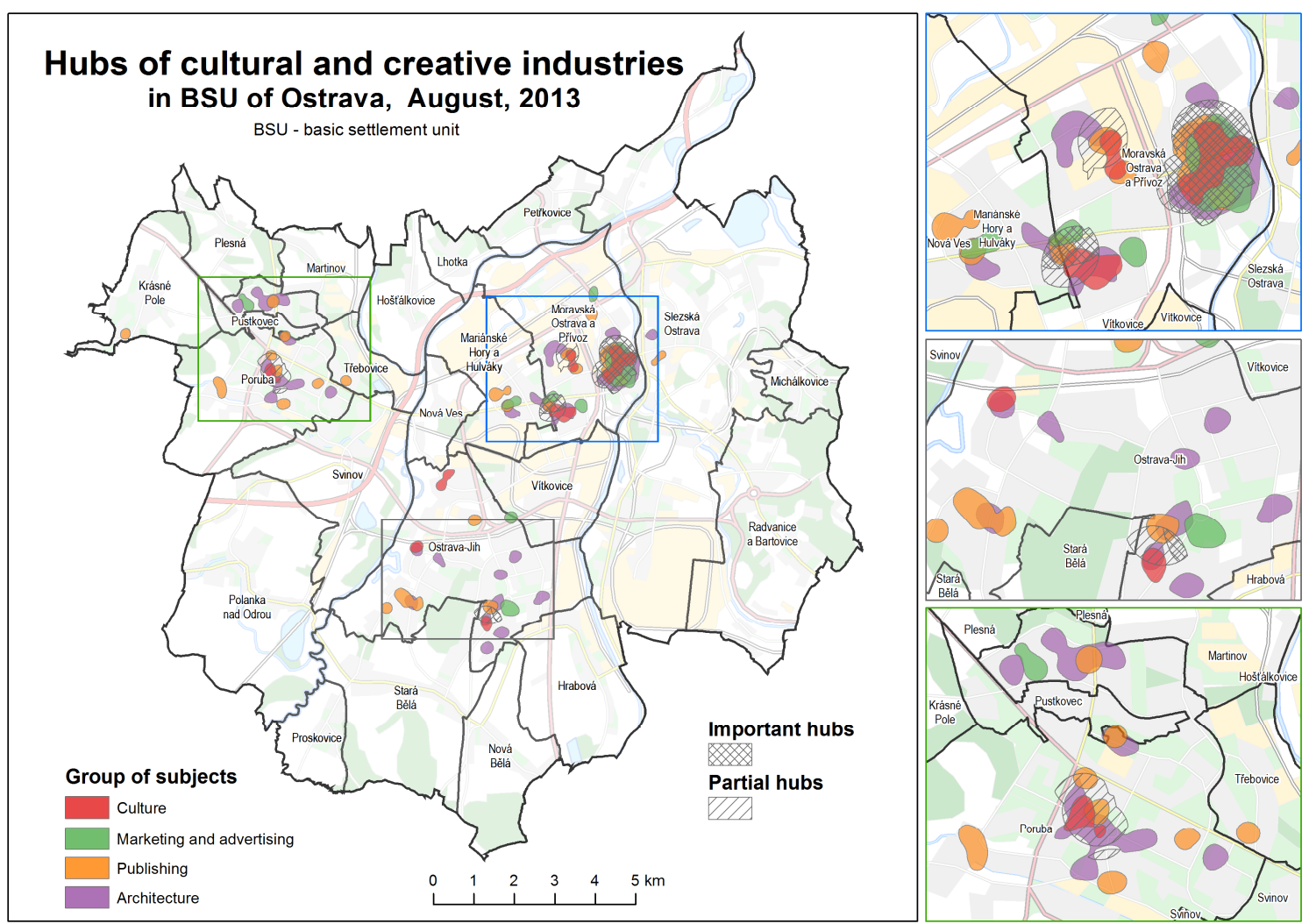

Fig. 1 - Localization of cultural and creative industries hubs in Ostrava. Source: Registry of Economic Subjects (RES) of the Czech Statistical Office (2013)

\section{Results}

At the first level of the analysis, the clustering/dispersion of the creative industries was studied using the nearest neighbour method. It is expected that all results will tend to clustering compared to complete spatial randomness, thus NNI all subjects can be used as the etalon. Our results show that clustering is predominant - most significantly in case of marketing and advertising, and the least significantly in case of printing. In comparison will all subjects, companies in all creative industries are less clustered (Fig. 1, Table 2). To compare NNIs with another etalon, NNI for all address points (31,569 points) in Ostrava was calculated, that is equal to 0.604. All analysed creative industries are more clustered compared to all address within the city. It has not been calculated $\mathrm{NNI}$ for all economical subjects or for all service 
oriented companies in the city, due to problems with geocoding that is very time-consuming. It is expected, that resulting NNI would be between NNI for all address and NNI for subjects from creative industries.

Table 2 - Nearest neighbour index by selected creative industries. Source: Registry of Economic Subjects (RES) of the Czech Statistical Office (2013) Note: * statistically significant

\begin{tabular}{ll} 
Branches & NNI \\
\hline All subjects & $0.408^{*}$ \\
Culture & $0.552^{*}$ \\
Marketing and advertising & $0.474^{*}$ \\
Printing & $0.603^{*}$ \\
Publishing & $0.505^{*}$ \\
Architecture & $0.583^{*}$
\end{tabular}

From the perspective of distribution at the level of individual branches the following patterns can be identified:

- Culture (139 subjects, see Fig. 2) is concentrated predominantly into the historic centre and represented particularly by large subjects. At the same time the polycentric character of the spatial distribution of culture in Ostrava is visible. This is documented by the fact that the concentration of culture can be tracked down also in central parts of Ostrava's subcentres - Poruba and Ostrava-Jih - only with a lower concentration.

- Marketing and advertising companies (902 subjects, see Fig. 3 ) are located again in the inner city with dominance of the historic centre. A high concentration is also in other parts of the wider inner city (Přivoz, Mariánské Hory). In Poruba and Ostrava-Jih are located mainly smaller companies. Simultaneously it seems that some companies with a higher number of employees are localized outside the sectoral clusters.

- The printing (133 subjects, see Fig. 4) shows the most dispersed distribution. Within the inner city can be traced the companies' localization outside the historic centre in the northwest direction (Prívoz), i.e. areas with lower urban density.
Ostrava-Jih has a higher representation of printing companies. Visible is also localization of large companies in peripheral parts of individual Ostrava's centres.

- Publishing activities (109 subjects, see Fig. 5) are mainly concentrated into the inner city, or respectively the historic centre. A significant representation can also be identified in the district of Mariánské Hory. In the other two subcentres the patterns are more dispersed.

- In architecture (302 subjects, see Fig. 6) dominates the historic centre. A large part of the companies localized in the inner city is situated to the East of the historic centre between the streets Nádražní and Poděbradova. In the other two sub-centres are present rather smaller companies. In Poruba, a higher concentration is visible in the proximity of the VSB-Technical University of Ostrava's campus.

Another level of the analysis was the identification of the selected creative industries' spatial co-localization at two levels. At the first level the executed correlation of the subjects' densities proved significant correlations among all branches (see Table 1). The highest correlation rate was identified for the marketing and advertising, and architecture. The lowest rate of co-localization among all branches were identified in printing.

The second level was the identification of creative industries' hubs with the exception of the printing, which comprised an empty set. The largest hub integrating all surveyed branches is localized in the historic centre and its immediate surroundings. In the inner city are also localized two significant hubs. In the western part is a hub with dominance of architecture, complemented with culture and publishing. To the south is also a hub with similar sectoral mix complemented with marketing and advertising. The hub in Poruba stretches from the VSB-Technical University of Ostrava's campus along the main shopping street. In Ostrava-Jih was not identified any significant hub. 


\section{Discussion}

From the perspective of spatial clustering/dispersion of creative industries the assumption of the knowledge base (symbolic/synthetic) influence was supported, which is documented by the difference between printing and marketing/advertising, or respectively publishing. The lower degree of clustering in architecture indicates the validity of the presumed influence of the synthetic knowledge base. The lower clustering rate of culture, in contrast with marketing/advertising, is rather of purely contextual nature (the polycentric character of the city).

Our results show that the surveyed content origination oriented creative industries have a tendency to spatially concentrate particularly into the historic centre and inner city. The identified spatial patterns imply the key importance of intensity of urbanization economies (with the exception of printing). Spatial patterns of individual branches show relatively similar features, however they are by far not identical. The key role in culture is played by accessibility and centrality. Simultaneously the polycentric character is also visible, although the privileged position of the city centre in the framework of the intra-urban hierarchy is still maintained. Publishing, marketing, and advertising have relatively similar patterns, while for both branches is proving the tendency of large companies to spatial de-concentration. Architecture is also concentrated in the inner city; however here is not as visible the tendency towards the spatial de-concentration of large companies. On the contrary, the inner city is a "showcase" of large architectonic companies, while the other sub-centres are dominated by small companies. As for printing - here is illustratively reflected the higher importance of the scale economies, and primarily the internal scale economies, which is mainly the case of large companies.

The studied creative industries have a high tendency towards spatial co-localization, which corresponds with the similarly focused studies (Musterd, Deurloo 2006; Currid, Williams 2010).
The lowest correlation rate had the printing, again in line with the theoretical assumption, while surprisingly the lowest rate in relation to publishing, that is the most related branch from the production chain perspective. It seems that a more important factor than the spatial proximity is rather the internal scale economies, forcing the printing outside urbanized areas.

The highest spatial concentration of the selected branches was identified through the hubs, which enabled to identify at a micro-level the scope of concentration without the necessity of taking into account the administrative borders (BSU). From the perspective of the size, diversity, and significance dominates the hub stretching around the historic centre. It can be thus assumed that it is exactly this space where the urbanization economies are the most intensive. The other two hubs in the inner city are differing not only with their scope, but also with the lower rate of diversity. Especially the hub flanking to the historic centre is dominated by architecture, which can vice versa imply the higher significance of the localization economies. Similar situation is with the hub in Poruba, for which the role and importance of the spatial proximity of the technical university will be necessary to study in a more detail in the future. A deeper analysis should be also elaborated with respect to the spatial co-localization of creative industries and residential orientation of employees in such companies (see Musterd, Deurloo 2006). A preceding research (Musil, Ivan 2010) points out a possible gentrification process in the southeastern part of the historic centre and inner city, which spatially overlaps with the main hub of creative industries.

Unlike retail business (Bednár 2008), the creative industries retain its urban character and a relative centrality. In this context it will be highly interesting how the gradual decline of the city centre, as a result of the construction of the Nová Karolina flagship project on the threshold of the historic centre (Rumpel, Slach 2012), will impact on the main hub of creative industries. 


\section{Conclusions}

This paper aimed to study a micro-geographical organization of creative industries at intra-urban level. The studied area was a polycentric, postsocialistic, and industrial city of Ostrava. The main conclusions can be summarized as follows: It was confirmed that creative industries demonstrate the assumed spatial heterogeneity, and that it is necessary to perceive them as a set of differentiated (although related) branches. The identified spatial characteristics like tendency towards spatial co-localization and tendency towards clustering with preference of highly dense built-up areas in the inner cities imply a high probability of the importance of factors outlined in the theoretical part It seems that despite a number of context-specific factors in the form of a polycentric city structure, low presence of creative industries, and their lower knowledge demands, the spatial patterns that are not much different from their counterparts in Western economies are predominating.

However, it is necessary to stress that the results of this study also have some limitations. Their interpretation is based mainly on the so-called "first law of geography" (Tobler 1970). However, the spatial proximity does not always generate other forms of proximity (Boschma 2005). It is thus suitable to perceive the presented text as a certain form of an extensive research (Sayer 1992). Therefore, it is desirable to extend the research of creative industries in the sense of an intensive research heading towards the more qualitative-oriented research (for illustration e.g. Chapain, Comunian 2010). This will contribute to a better and more complex understanding of the creative industries, and their networks inside clusters (hubs), and outside of them. In this field still exists a large space for further research.

\section{Acknowledgements}

We would like to thank Jiři Ježek and two anonymous reviewers for their helpful comments and suggestions. Any errors and omissions remain the author's responsibility.

The authors acknowledge support of the Czech Science Foundation, research grant no. 14-
268315 and support from the Technology Agency of the Czech Republic, research grant no. TD020323.

\section{References}

Asheim B, Coenen L, Vang J (2007) Face-to-face, buzz, and knowledge bases: sociospatial implications for learning, innovation, and innovation policy. Environment and Planning C 25: 655-670.

Bednář P (2008) Geografie transformace maloobchodní sítě města Ostravy. Disertační práce, Katedra sociální geografie a regionálního rozvoje PřF UK, Praha.

Bednář P, Grebeníček P (2012) Emerging Creative Cities: Mapping Regional Capitals in the Czech Republic and Slovakia. Advances in Economics, Risk Management, political and law science: 178-183.

Boggs J (2009) Cultural industries and the creative economy-vague but useful concepts. Geography Compass 3: 1483-1498.

Boix R (2013) Creative industries in Spain: the case of printing and publishing. In: Lazzeretti L (ed.) Creative Industries and Innovation in Europe: Concepts, Measures and Comparative Case Studies. Routledge, London, pp. 65-85.

Boschma R (2005) Proximity and innovation: a critical assessment. Regional studies 39: 61-74.

Campbell P (2014) Imaginary Success?-The Contentious Ascendance of Creativity. European Planning Studies 22: 995-1009.

Caves R E (2000) Creative Industries: Contracts Between Art And Commerce. Harvard University Press, Cambridge, MA.

Caves R E (2003) Contracts between art and commerce. Journal of economic perspectives 17 : 73-83.

Cruz S S, Teixeira A A (2015) The neglected heterogeneity of spatial agglomeration and colocation patterns of creative employment: evidence from Portugal. The Annals of Regional Science 54: 143-177.

Currid E., Williams S (2010) Two Cities, Five Industries: Similarities and Differences within and between Cultural Industries in New York and Los Angeles. Journal of Planning Education and Research 29: 322-335.

David Q, Peeters D, Van Hamme G, Vandermotten C (2013) Is bigger better? Economic performances of European cities, 1960-2009. Cities 35: 237-254. 
DCMS (Department of Culture, Media and Sport) (1998) Creative Industries Mapping Document. London: HMSO.

De Propris L, Chapain C, Cooke P, MacNeill S, MateosGarcia J (2009) The geography of creativity, NESTA Interim Report. NESTA, London.

Drake G (2003) His place gives me space: place and creativity in the creative industries. Geoforum 34: 511-524.

Ebert R, Kunzmann K R (2007) Kulturwirtschaft, kreative Räume und Stadtentwicklung in Berlin. disP-The Planning Review 171: 64-79.

Glaeser E L, Henderson V, Inman R P (2000) The Future of Urban Research: Nonmarket Interactions [with Comments]. Brookings-Wharton papers on urban affairs: 101-149.

Grabher G (2002) The Project Ecology of Advertising: Tasks, Talents and Teams. Regional Studies 36: 245-262.

Grabher G (2004) Learning in projects, remembering in networks? Communality, sociality, and connectivity in project ecologies. European urban and regional studies 11: 103-123.

Hampl, M. (2005) Geografická organizace společnosti v České republice: transformační procesy a jejich obecný kontext. Univerzita Karlova v Praze, Př́rodovědecká fakulta, Katedra sociální geografie a regionálního rozvoje, Praha.

Havrlant M (1980) Geografie Severomoravského kraje. Pedagogická fakulta v Ostravě, Ostrava.

Heebels B (2013) Place-making in publishing: Dutch trade book publishers and the meaning of place in establishing reputation and trust. Geoforum 45: 248-258.

Hitters E, Richards G (2002) The creation and management of cultural clusters. Creativity and innovation management 11: 234-247.

Hjorth-Andersen C (2003) The Economics of Publishing. In: Towse R (ed.) A Handbook of Cultural Economics. Edward Elgar Publishing, Cheltenham, UK, pp. 399-407.

Hutton T A (2004). The new economy of the inner city. Cities 21: 89-108.

Hutton T A (2006) Spatiality, built form, and creative industry development in the inner city. Enviroment and Planning A 38: 1819-1843.

Chapain C, Comunian R (2010) Enabling and inhibiting the creative economy: The role of the local and regional dimensions in England. Regional Studies 44: 717-734.
Inspektor T, Ivan I, Horák J (2014) Mapping and Monitoring Unemployment Hot Spots towards Identification of Socially Excluded Localities: case study of Ostrava. Journal of Maps 10: 35-46.

Keeble D, Nachum L (2002) Why do business service firms cluster? Small consultancies, clustering and decentralization in London and Southern England. Transactions of the Institute of British Geographers 27: 67-90.

Kloosterman R C (2004) Recent employment trends in the cultural industries in Amsterdam, Rotterdam, The Hague and Utrecht: A first exploration. Tijdschrift voor economische en sociale geografie 95: 243-252.

Kloosterman R, Stegmeijer E (2004) Cultural industries in the Netherlands-path-dependent patterns and institutional contexts: the case of architecture in Rotterdam. Petermanns Geographische Mitteilungen 148: 66-73.

Kloosterman R C (2008) Walls and bridges: knowledge spillover between 'superdutch' architectural firms. Journal of Economic Geography 8: 1-19

Kloosterman R C (2010) Building a career: labour practices and cluster reproduction in Dutch architectural design. Regional Studies 44: 859-871.

Kunc J, Martinát S, Tonev P, Frantál B (2014) Destiny of urban brownfields: Spatial patterns and perceived consequences of post-socialistic deindustrialization. Transylvanian Review of Administrative Sciences 41: 109-128.

Kuta V, Kuda F, Sedlecký J (2005) Černá louka-první poválečný brownfield $v$ Ostravě. Urbanismus a územní rozvoj 8: 10-15.

Lazzaretti L, Boix R, Capone F (2008) Do creative industries cluster? Mapping creative local production systems in Italy and Spain. Industry and Innovation 15: 549-567.

Levine N (2007) CrimeStat: A spatial statistics program for the analysis of crime incident locations (v3.1). N Levine \& Associates, Houston, TX, and the National Inst. of Justice, Washington, DC.

Malmberg A, Maskell S (2002) The elusive concept of localization economies: towards a knowledgebased theory of spatial clustering. Environment and Planning A 34: 429-449.

Maoh H, Kanaroglou P (2007) Geographic clustering of firms and urban form: a multivariate analysis. Journal of Geographical Systems 9: 29-52.

Markusen A (2006). Urban development and the politics of a creative class: evidence from a study of 
artists. Environment and planning A 38: 19211940.

Molotch H (2002) Place in product. International Journal of urban and regional research 26: 665688.

Mommaas H (2004) Cultural clusters and the postindustrial city: Towards the remapping of urban cultural policy. Urban Studies 41: 507-532.

Musil J, Ivan I (2010): Studie o změnách sociálně prostorové struktury Ostravy mezi rokem 1966 a 2010. In: Hruška-Tvrdý L (eds.) Industriální město v postindustriální společnosti 2. díl. Accendo, Ostrava.

Musterd S, Deurloo R (2006) Amsterdam and the preconditions for a creative knowledge city. Tijdschrift voor economische en sociale geografie 97: 80-94.

Nachum L, Keeble D (2003) Neo-Marshallian clusters and global networks: the linkages of media firms in central London. Long Range Planning 36: 459-480.

O'Sullivan D, Unwin D J (2010) Geographic Information Analysis. Wiley, New York.

Oldenburg R (1999) The Great Good Place. Marlow, New York.

Power D (2003) The nordic 'cultural industires': A crossnational assessment of the place of the cultural industries in Denmark, Finland, Norway and Sweden. Geografiska Annaler B 85: 167-180.

Pratt A C (2004) Mapping the cultural industries: Regionalization; the example of south east England. In: Power D, Scott A J (eds.) Cultural industries and the production of culture. Routledge, London, pp. 19-36.

Pratt A C (2005) Cultural industries public policy: An oxymoron? International Journal of Cultural Policy 11: 31-44.

Pratt A C (2013) The cultural and creative industries: Organisational and spatial challenges to their governance. DIE ERDE-Journal of the Geographical Society of Berlin 143: 317-334.

Rehák Š, Chovanec M (2012) Exploring Spatial Patterns of Creative Industries with Firm Level Micro Geographic Data. Region Direct 5: 10-35.

Rehák, Š, Maier G, Buček M (2013) The Spatial Pattern of Creative Industries in a Transformation Economy: The Case of Slovakia, Mitteilungen der Österreichischen Geographischen Gesellschaft 55: 195-219
Rogerson P (2010) Statistical Methods for Geography. Sage, London.

Rozentale I, Lavanga M (2014) The "universal" characteristics of creative industries revisited: The case of Riga. City, Culture and Society 5: 55-64.

Rumpel P, Slach O (2012) Governance of shrinkage of the city of Ostrava. European Science and Art Publishing, Praha.

Sayer A (1992) Method in social science: A realist approach. Routledge, Hutchinson.

Scott A J (2000) The Cultural Economy of Cities: Essays on the Geography of Image-Producing Industries. Sage, London.

Slach O, Koutský J, Novotný J, Ženka J (2013) Creative Industries in The Czech Republic: A Spatial Perspective. E+ M Ekonomie a Management 8: 1429.

Stam E, De Jong J P, Marlet G (2008). Creative industries in the Netherlands: Structure, development, innovativeness and effects on urban growth. Geografiska Annaler: Series B 90: 119-132.

Strambach S (2008) Knowledge-Intensive Business Services (KIBS) as drivers of multilevel knowledge dynamics. International Journal of Services Technology and Management 10: 152-174.

Thiel J (2007) Räumlicher Strukturwandel der (west-) deutschen Werbewirtschaft. Arbeitsmärkte als lokale Anker der Kreativökonomie? Zeitschrift für Wirtschaftsgeographie 51: 31-45.

Throsby D (2008) Modelling the cultural industries. International Journal of Cultural Policy 14: 217232.

Tobler W R (1970) A computer movie simulating urban growth in the Detroit region. Economic geography 46: 234-240.

Turok I (2004) Cities, regions and competitiveness. Regional Studies 38: 1069-1083.

Vybíral J (2003) Zrození velkoměsta -- Architektura v obraze Moravské Ostravy 1890-1938. Era, Praha.

Wong D W S (2009) The Modifiable Areal Unit Problem (MAUP). In: Fotheringham S A, Rogerson P A (eds.) The SAGE Handbook of Spatial Analysis. Sage, London, pp. 105-123. 


\section{Appendix A - Spatial distribution of individual $\mathrm{Cl}$ in Ostrava}
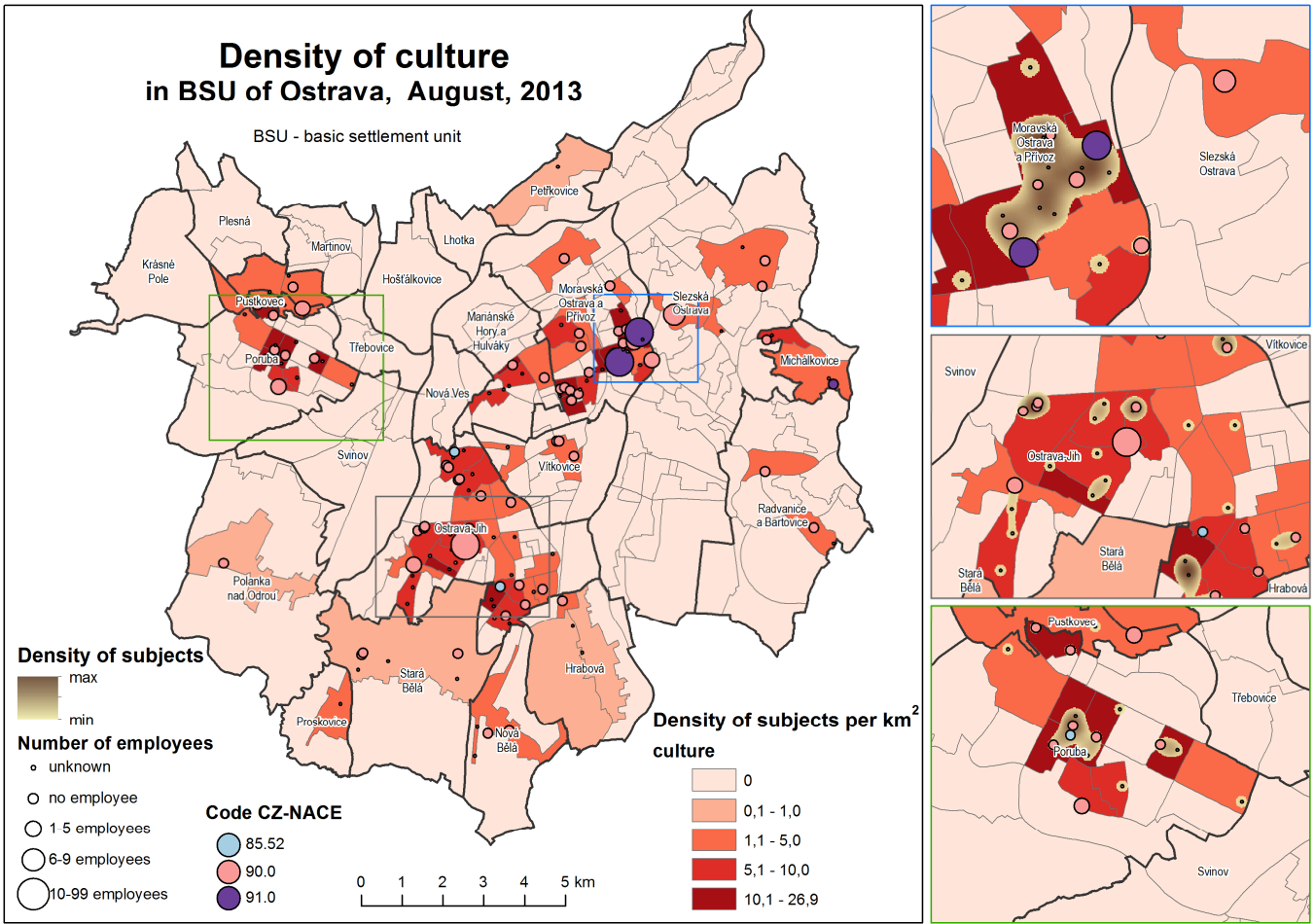

Fig.2 - Spatial distribution of culture in Ostrava. Source: Registry of Economic Subjects (RES) of the Czech Statistical Office (2013)
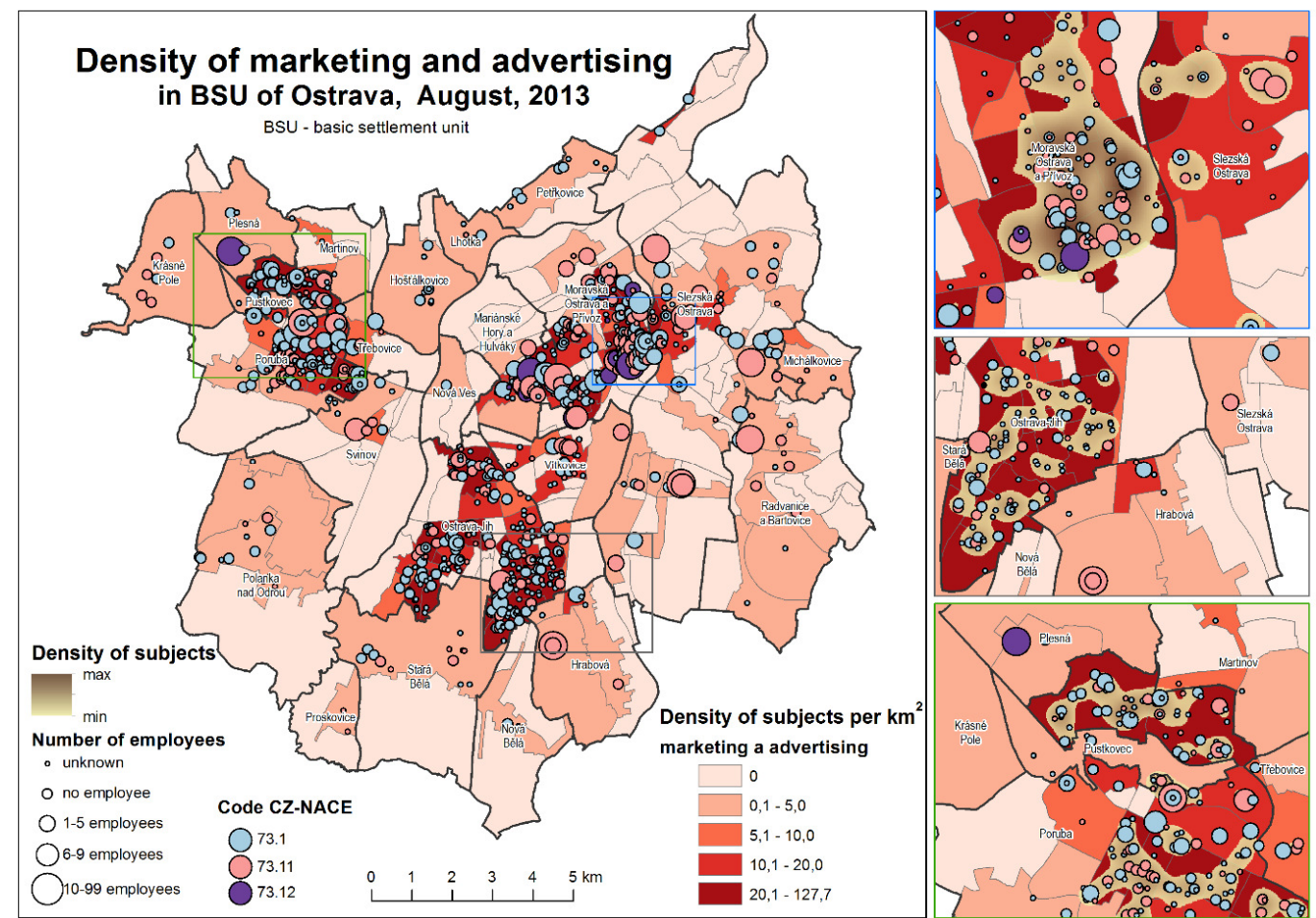

Fig. 3 - Spatial distribution of marketing/advertising in Ostrava. Source: Registry of Economic Subjects (RES) of the Czech Statistical Office (2013) 

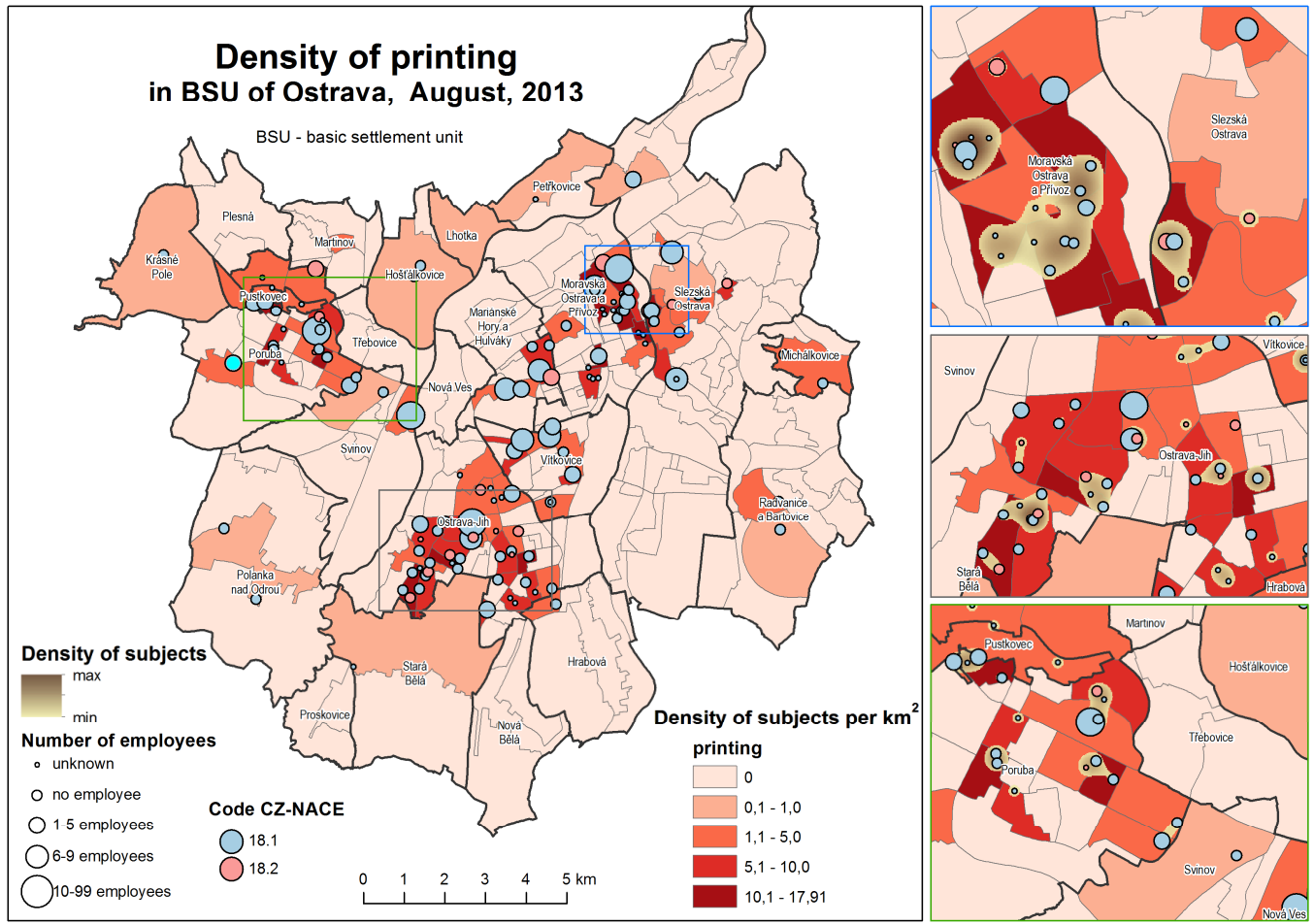

Fig. 4 - Spatial distribution of printing in Ostrava. Source: Registry of Economic Subjects (RES) of the Czech Statistical Office (2013)
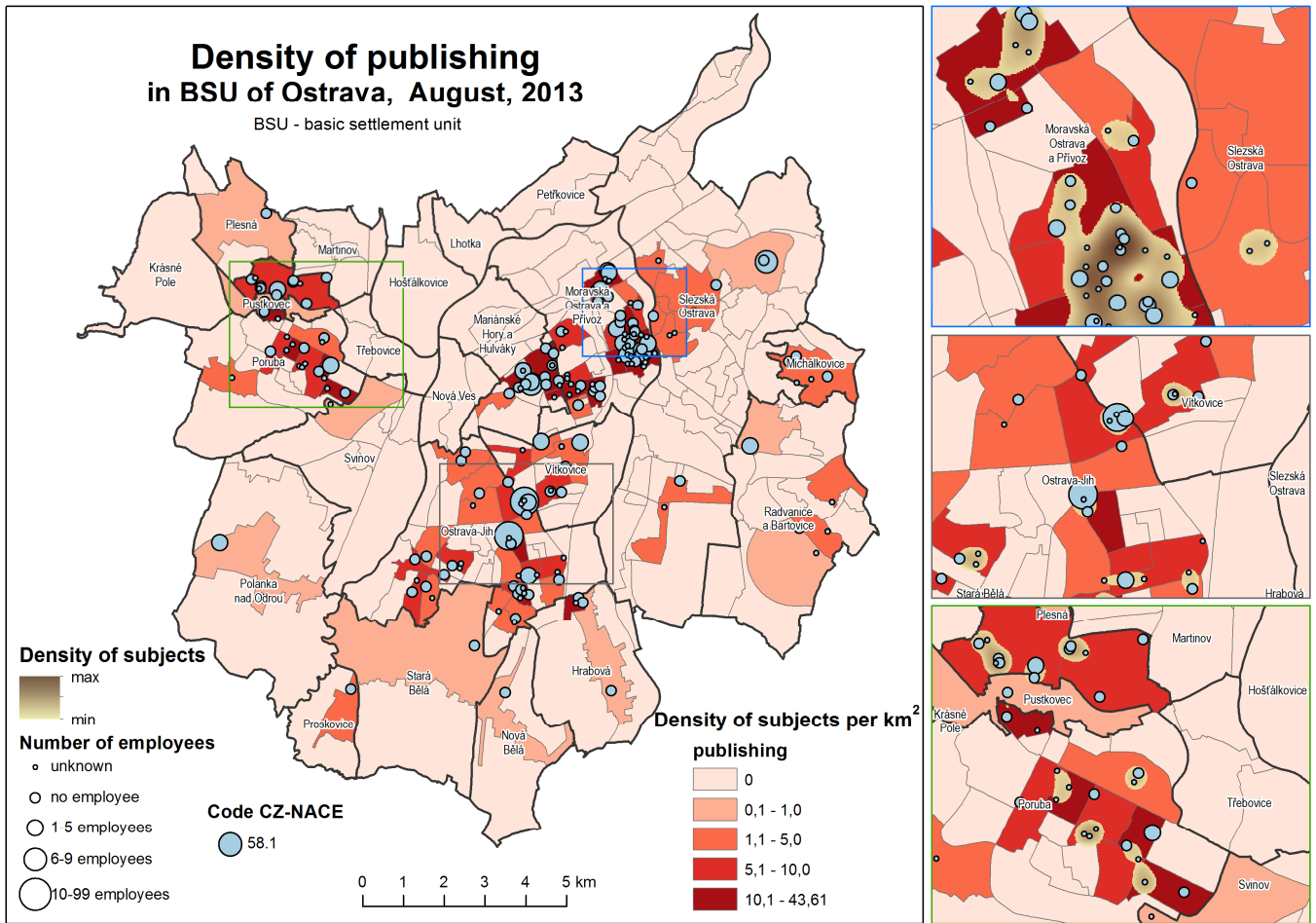

Fig. 5 - Spatial distribution of publishing in Ostrava. Source: Registry of Economic Subjects (RES) of the Czech Statistical Office (2013) 

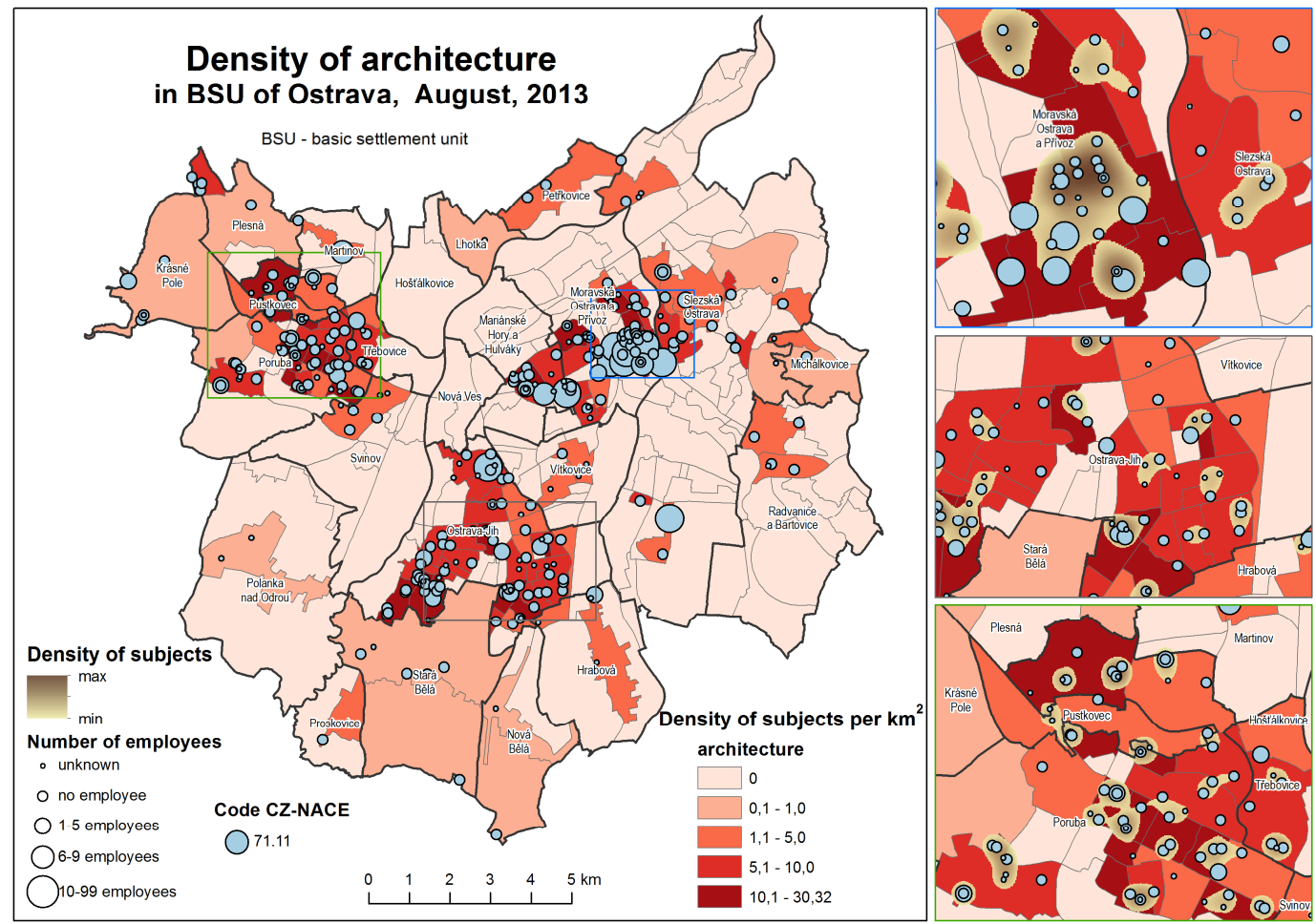

Fig. 6 - Spatial distribution of architecture in Ostrava. Source: Registry of Economic Subjects (RES) of the Czech Statistical Office (2013) 


\section{Appendix B - List of creative industries branches and relevant NACE}

Table 3 - List of creative industries branches and relevant NACE rev.2 classifier

NACE Sector

18 Printing and reproduction of recorded media

18.1 Printing and service activities related to printing

18.2 Reproduction of recorded media

58 Publishing activities

58.1 Publishing of books, periodicals and other publishing activities

71 Architectural and engineering activities; technical testing and analysis

71.1 Architectural and engineering activities and related technical consultancy

71.11 Architectural activities

73 Advertising and market research

73.1 Advertising

73.11 Advertising agencies

73.12 Media representation

85 Education

85.5 Other education

85.52 Cultural education

90 Creative, arts and entertainment activities

90.0 Creative, arts and entertainment activities

91 Libraries, archives, museums and other cultural activities

91.0 Libraries, archives, museums and other cultural activities 